\title{
CHARACTERIZATION OF RHIZOBIUM ISOLATED FROM ROOT NODULE OF PEA (PISUM SATIVUM L.)
}

\author{
ABDOUSLAM M. RASSEM ${ }^{1}$ \& ARUN A. DAVID ${ }^{2}$ \\ ${ }^{1}$ Research Scholar Department of Soil Science, Sam Higginbottom University of Agriculture, \\ Technology \& Sciences Allahabad, U.P., India \\ ${ }^{2}$ Associate Professor Department of Soil Science, Sam Higginbottom University of Agriculture, \\ Technology \& Sciences Allahabad, U.P., India
}

Studies were conducted on root nodules, collected from young and healthy seedling of pea, at research farm of soil science, Naini Agricultural Institute, Allahabad (SHUATS), U.P, India. The isolates were further subjected to morphological, biochemical and physiological (stress tolerance) characterization; three Rhizobium strains were isolated from the root nodule of field pea and characterized by standard biochemical tests. Isolated Rhizobia was fast grower, all strains were gram-negative rod and creamy color colony. Rhizobium strains showed difference in chemical test and urea hydrolysis, and the strains utilized glucose and mannitol as fermentation sugar, growth of Rhizobium strains tolerated to stress as temperature were at $20^{\circ} \mathrm{C}$ and $28^{\circ} \mathrm{C}$, also observed well growth of sinorhizobium meliloti and rhizobium pusense strains at $2 \% \mathrm{NaCl}$, while leguminosarum strain was grown at $3 \% \mathrm{NaCl}$, and all strains were grown at pH 6 and pH 7. Optimum conditions help to enhance plant and super strain for fixed nitrogen in nodules of field pea crop. KEYWORDS: Rhizobium Characterization, Biochemical Tests, Field Pea \& Stress Tolerance
\end{abstract}

Received: Jun 06, 2017; Accepted: Jun 20, 2017; Published: Jul 12, 2017; Paper Id: IJASRAUG201724

\section{INTRODUCTION}

The soil includes many types of microorganisms such as bacteria, actinomycetes, fungi, and algae, which are important because, they affect the physical, chemical, and biological properties of soil and growth plant amongst the soil bacteria, a unique group called, rhizobia having a beneficial effect on the growth of plants. It can live either in the soil or within the root nodules of host legumes. The bacteria colonize within root nodules, where it converts atmospheric nitrogen to ammonia and provides organic nitrogenous compounds to the plants. In legumes and a few other plants, the bacteria live in small outgrowths on the roots called nodules, within these nodules, the bacteria do nitrogen fixation, and the plant absorbs the ammonia (Oblisami, 1995)

Legumes have been used in agriculture since ancient times, and legume seeds or pulses were among the first source of human food and their domestication. Legume plant possesses a unique ability to establish a symbiosis with nitrogen-fixing bacteria of the family rhizobiaceae. The bacteria belonging to the genera Rhizobium, Bradyrhizobium, Allorhizobium, Rinorhizobium and Mesorhizobium (Willams, 2006), which are collectively referred to as rhizobia, are able to form nodules on their host plants, and the fixation of $\mathrm{N}_{2}$ by legumes plays a key role in agricultural sustainability. Moreover, the further assessment of rhizobium genetic diversity is contributing both to the world wide knowledge of biodiversity of soil micro-organisms and to the usefulness of rhizobium collections, and it is developing long-term strategies to increase contributions of legume-fixed to 
agricultural productivity. Low soil $\mathrm{pH}$ does not allow the rhizobium cells to survive inadequate numbers in free-living state, consequently it becomes inevitable to inoculate the crop in adequate rhizobium (Deka et al., 2006). Increasing salt concentration may have detrimental effects on rhizobium population (Singleton et al., 1992) among the factors that affect growth and survival of these genera. There have been reports of the detrimental effects of salt stress on plant growth, multiplication of rhizobia, nodulation and nitrogen fixation (Embalomatis, et al., 1994). The harmful effect of salinity on rhizobia and bradyrhizobia may be due to direct specific ion effects or to the indirect effect of salinity, by raising the $\mathrm{pH}$ value and decreasing osmotic potential. Salt tolerant rhizobia may have the potential to improve yield of legumes under salinity stress (El-Mokadem, 1991). rhizobium inoculation increases nodule biomass, thus encourages sustainable environmental friendly agriculture by responding perfectly in biological nitrogen fixation (Adewusi et al., 2008). Various researches demonstrated the ability of rhizobium to colonize roots of nonlegumes (Matiru et al., 2004) and act as phytohormone producer, phosphate solubilizer and to some extent, as nitrogen fixer (Afzal et al., 2008). Bio-fertilizer promotes plant growth and productivity, which has internationally been accepted as an alternative source of chemical fertilizer. Rhizobacteria effectively colonize plant root and increases plant growth by production of various plant growth hormones, P-solubilizing activity, $\mathrm{N}_{2}$ fixation and biological control activity (Deshwal et al., 2011). Modulated wild legumes have potential for nitrogen fixation, reforestation and to control soil erosion (Elsoni et al., 2011).

\section{MATERIALS AND METHODS}

\section{Study Area}

This study was conducted in the district during 2015-16, the sample was collected from the research farm of soil science, Naini Agricultural Institute (NAI), Allahabad (SHUATS) at a latitude of $20^{\circ} 15^{\circ}$ North and longitude of $60^{\circ} 3^{\circ}$ East, and at an altitude of 98 meters, above mean sea level (MSL).

\section{Procedure}

Three samples of root nodules from field pea (Pisum sativum L.) were collected randomly from different localities. From each plant sampled, three to four nodules were at random excised and healthy root nodules were washed with tape water thrice, before streaking on agar plate as described by (Vincent, 1970; Ben-Gweirif et al., 2005). The nodules were sterilized externally, using $95 \%$ alcohol for 1-4 minute, followed by washing with calcium hypochlorite solution $(10 \mathrm{~g} / 150 \mathrm{ml}$ distilled water) and crushing in a drop of sterile water. A loopful ground material was transferred to $5 \mathrm{ml}$ of sterile water, of which, $0.1 \mathrm{ml}$ sample was spread onto the surface of yeast extract manitol agar (YEMA). Plates were then incubated at $28^{\circ} \mathrm{C}$ for 48 hours; well isolated typical single colonies were re-streaked on freshly prepared YEMA plates, in order to obtain pure cultures to study morphological, cultural and biochemical characteristics.

\section{Morphological Characteristics}

Morphological characteristics of colour, shape, morphology and colony were observed under low power microscope, similarly using gram staining technique, as described by (Arora, 2003).

\section{Biochemical Tests}

All the collected samples were processed through different biochemical tests for identification, and studied characters of strains isolated and biochemical tests were carried out viz, catalase test (Facklam and Elliott, 1995), indole production test (MacFaddin, 2000) methyl red and vogas proskauer test (Vogesand Proskauer, 1898), citrate utilization test as described by (Claus, 1989) and starch hydrolysis test as mentioned by (Arora, 2003), urease test (Collins and Patricia, 
1995), casein hydrolysis test (Salisbury et al., 1972) and mannitol fermentation as mentioned by (Cappuccino, 2008)

\section{Salt, pH and Temperature Tolerance}

Physiological test range of salt, $\mathrm{pH}$ and temperature tolerance for growth optimum, the ability of the isolated rhizobium strain to grow in different concentration of salt was tested by streaking them on YEM medium containing $1.0 \%$, $2.0 \%, 3.0 \%, 4.0 \%, 4.5 \%$ and $5.0 \%$ (w/v) NaCl. After five days of incubation, the absorbance of the resultant growth of the bacteria in the broth tubes was measured using a spectrophotometer at a wavelength $540 \mathrm{~nm}$, as described by (Vincent, 1970; Rafiq, 1997). The differences in $\mathrm{pH}$ tolerance were adjusted with the $\mathrm{pH}$ to 4.0, 5.0, 6.0, 7.0 and 8.0. All the plates were incubated at $28^{\circ} \mathrm{C}$ for 72 hours and YEM medium plates were used as controls. The difference in the range of growth temperature was investigated by incubation of bacterial cultures at $5^{\circ} \mathrm{C}, 10^{\circ} \mathrm{C}, 15^{\circ} \mathrm{C}, 20^{\circ} \mathrm{C}, 28^{\circ} \mathrm{C}, 38^{\circ} \mathrm{C}, 40^{\circ} \mathrm{C}, 45^{\circ} \mathrm{C}$ and $50^{\circ} \mathrm{C}$. Control plates were incubated at $28^{\circ} \mathrm{C}$, after incubation, the absorbance of the result growth of the bacteria in the broth tubes was measured using a spectrophotometer, at a wavelength $540 \mathrm{~nm}$ as described by (Vincent, 1970; Gao et al., 1994; Mensah et al., 2006).

\section{RESULTS AND CONCLUSION}

In the study, three strains were isolated (Table 1) from root nodules of (Pisum sativum L.) collected from different locations in Allahabad

Table 1: Isolates of Bacteria from Root Nodules of Pea

\begin{tabular}{|l|l|l|}
\hline SR. No. & \multicolumn{1}{|c|}{ Name of the Isolate } & \multicolumn{1}{c|}{ Location of Isolates } \\
\hline 1 & $\mathrm{RS}_{1^{-}}[$Leguminosarum $]$ & Soil Science Research Farm \\
\hline 2 & $\mathrm{RS}_{2}-[$ Sinorhizobiu meliloti $]$ & Soil Science Research Farm \\
\hline 3 & $\mathrm{RS}_{3}-[$ Rhizobium pusense $]$ & Soil Science Research Farm \\
\hline
\end{tabular}

All strains tested were found to have rod colonies with regular borders, flat in elevation, creamy in colour after 3 to 5 days of growth on YEMA at $28^{\circ} \mathrm{C}$, on the basis of morphological isolates (Table 2). The colony were observed under low power microscope, by using a gram staining technique as described by (Arora, 2003), and pink colour gram negative rods were observed.

Three samples of root nodules from pea (Pisum sativa L.) were found, one strain positive for the presence of legminosurm. After screening through a series of various biochemical tests, one strain was characterized biochemically as legminosurm gram negative rods with circular, raised and smooth edges colony observed. These findings are in line with (Hussain et al., 2002; Oblisami, 1995), who also isolated the rhizobium legminosurm from pea with same Characteristics.

All the samples were also streaked on yeast extract mannitol (YEM) in selective media, for further confirmation. Similarly, the positive samples from all target areas showed hazy appearance in the motility media, and also were positive for catalase, glucose fermentation, mannitol fermentation tests, indole production test and starch hydrolysis test, and were found negative for methyl red (MR), voges-proskauer (VP), urea hydrolysis tests, casein hydrolysis test and citrate utilization test. These findings are in close agreement with (Elsheikh and Wood, 1989; Javed and Asghari, 2008), who also characterized the rhizobium from soil, and sunflower root nodules with the same positive biochemical tests. Similarly, (Oblisami, 1995) also studied the nodulation pattern in forage legume bacteria, by screening through the same tests results, and (Singh et al., 2008) characterized rhizobium strain from the roots of Trigonella foenumgraecum. 
Table 2: Morphological and Biochemical Characterization of Rhizobium Isolated From Pea

\begin{tabular}{|l|l|l|l|l|}
\hline \multirow{2}{*}{ S.No. } & \multirow{2}{*}{ Particulars } & \multicolumn{3}{c|}{ Strain of Rhizobium } \\
\cline { 3 - 5 } & & \multicolumn{1}{|c|}{$\mathbf{R S}_{\mathbf{1}}$} & \multicolumn{1}{c|}{$\mathbf{R S}_{\mathbf{2}}$} & \multicolumn{1}{|c|}{$\mathbf{R S}_{\mathbf{3}}$} \\
\hline 1 & Gram stain -reaction & - & - & - \\
\hline 2 & Colony morphology & rod & rod & Rod \\
\hline 3 & Colony colour & Creamy & Creamy & Creamy \\
\hline 4 & Methyl-red (MR) & - & - & + \\
\hline 5 & Voges-Proskauer tests (VP) & - & - & - \\
\hline 6 & Citrate utilization test & - & + & - \\
\hline 7 & Casein hydrolysis test & - & - & - \\
\hline 8 & Catalase Test & + & + & + \\
\hline 9 & Indole production test & + & - & - \\
\hline 10 & Urease test & - & + & + \\
\hline 11 & Starch hydrolysis test & + & + & + \\
\hline 12 & Glucose fermentation & + & + & + \\
\hline 13 & Mannitol fermentation & + & + & + \\
\hline
\end{tabular}

The motility media also were positive for $\mathrm{RS}_{2}$, and $\mathrm{RS}_{3}$ were positive for catalase, glucose fermentation, mannitol fermentation tests, urea hydrolysis tests and starch hydrolysis test and only positive $\mathrm{RS}_{3}$ for methyl red. $\mathrm{RS}_{2}$ and $\mathrm{RS}_{3}$ were found negative for methyl red (MR), voges-proskauer (VP), urea hydrolysis tests, casein hydrolysis test, casein hydrolysis test and indole production test as shown in table (2).

The physiological traits of three strains were summarized in Table 3 and 4, also in Figure 1, 2 and 3. The table 3 shows effected temperature tolerance on the strain, the maximum temperature where, more of the isolates' growth was $28^{\circ} \mathrm{C}$. The percentage of isolates grew well at 20 and $28^{\circ} \mathrm{C}$, and differentiation according to temperature tolerance started at $28^{\circ} \mathrm{C}$ and all the isolates were surviving at above temperature, and very low of the strains showed growth at temperature $5^{\circ} \mathrm{C}$ and $50^{\circ} \mathrm{C}$.

Table 3: Effected of Temperature on Rhizobium Isolated From Pea

\begin{tabular}{|l|c|c|c|c|c|c|c|c|c|}
\hline \multirow{2}{*}{ Strains } & \multicolumn{8}{|c|}{ Absorbance of Strain Rhizobium } \\
\cline { 2 - 11 } & $\mathbf{5}^{\mathbf{}} \mathbf{C}$ & $\mathbf{1 0}^{\circ} \mathbf{C}$ & $\mathbf{1 5}^{\circ} \mathbf{C}$ & $\mathbf{2 0}^{\circ} \mathbf{C}$ & $\mathbf{2 8}^{\circ} \mathbf{C}$ & $\mathbf{3 8}^{\circ} \mathbf{C}$ & $\mathbf{4 0}^{\circ} \mathbf{C}$ & $\mathbf{4 5}^{\circ} \mathbf{C}$ & $\mathbf{5 0}^{\circ} \mathbf{C}$ \\
\hline $\mathbf{R S}_{\mathbf{1}}$ & 0.07 & 0.13 & 0.28 & 0.37 & 0.48 & 0.36 & 0.28 & 0.20 & 0.16 \\
\hline $\mathbf{R S}_{\mathbf{2}}$ & 0.08 & 0.20 & 0.37 & 0.42 & 0.51 & 0.25 & 0.20 & 0.17 & 0.12 \\
\hline $\mathbf{R S}_{\mathbf{3}}$ & 0.09 & 0.23 & 0.40 & 0.57 & 0.63 & 0.57 & 0.52 & 0.47 & 0.39 \\
\hline
\end{tabular}

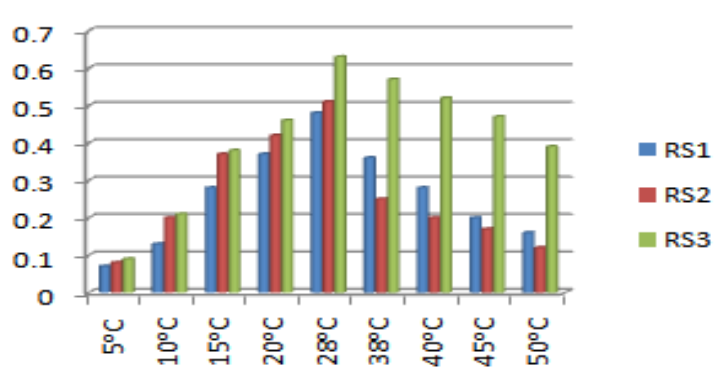

Figure 1: Effected of Temperature on Rhizobium Isolated From Pea

All rhizobia isolated were able to grow in all ranges of the various sodium chloride concentrations tested. The ability to tolerate high salt is far greater for the native strains, which grew less in above $2 \%$ sodium chloride concentrations of the medium (Table 4). But, the native rhizobium strains $\mathrm{RS}_{1}$ isolated were able to grow variably 
throughout the different sodium chloride range tested from $3 \%$ to $4 \%$, indicating the fact that, native rhizobium strains were more adapted to soils and highly concentrated with various forms of cations and anions, All strains were grown at controlled cultural conditions $\left(0.01 \% \mathrm{NaCl}, \mathrm{pH}\right.$ 7). All isolates strains $\mathrm{RS}_{2}$ and $\mathrm{RS}_{3}$ showed growth at $1.0 \%$ and decreased growth with increasing $\mathrm{NaCl}$ concentration, however, strain 1 showed good growth at $3.0 \% \mathrm{NaCl}$ concentration.

Table 4: Tolerance of Rhizobium Strains to pH and NaCl Concentrations

\begin{tabular}{|c|c|c|c|c|c|c|c|c|c|c|c|}
\hline \multirow{2}{*}{ Strains } & \multicolumn{5}{|c|}{ pH } & \multicolumn{6}{|c|}{$\mathrm{NaCl}(\mathrm{w} / \mathrm{v})$} \\
\hline & 4 & 5 & 6 & 7 & 8 & 1.0 & 2.0 & 3.0 & 4.0 & 4.5 & 5.0 \\
\hline $\mathbf{R S}_{\mathbf{1}}$ & 0.89 & 0.90 & 0.96 & 0.98 & 1 & 0.31 & 0.28 & 0.53 & 0.50 & 0.21 & 0.17 \\
\hline $\mathbf{R S}_{\mathbf{2}}$ & 0.30 & 0.33 & 0.40 & 0.44 & 0.44 & 0.55 & 0.48 & 0.35 & 0.32 & 0.25 & 0.20 \\
\hline $\mathbf{R S}_{\mathbf{3}}$ & 0.75 & 0.80 & 0.84 & 0.90 & 0.93 & 0.42 & 0.37 & 0.34 & 0.32 & 0.27 & 0.22 \\
\hline
\end{tabular}

A growth strain in a different range of $\mathrm{pH}$ was noted, when $\mathrm{pH}$ at 4 of all strains $\mathrm{RS}_{1}, \mathrm{RS}_{2}$ and $\mathrm{RS}_{3}$ decreased growth. Optimum $\mathrm{pH}$ range for rhizobia was between $\mathrm{pH} 6$ and $\mathrm{pH}$ 7, which was increasing growth as shown in table 4. No rhizobium strains were able to grow at $\mathrm{pH}$ of the medium adjusted to 4 , all the rest, including rhizobia were able to grow on the medium adjusted to $\mathrm{pH} 7$ (Table 4). In the soil environment, the condition is highly different. All the native rhizobium strains were able to survive well in the various soils adjusted to $\mathrm{pH} 4$ up to 7 .

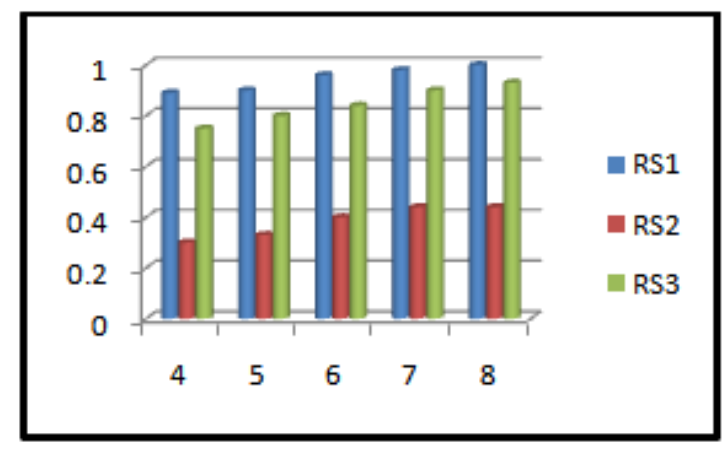

Figure 2: Tolerance of Rhizobium Strains to $\mathbf{P h}$

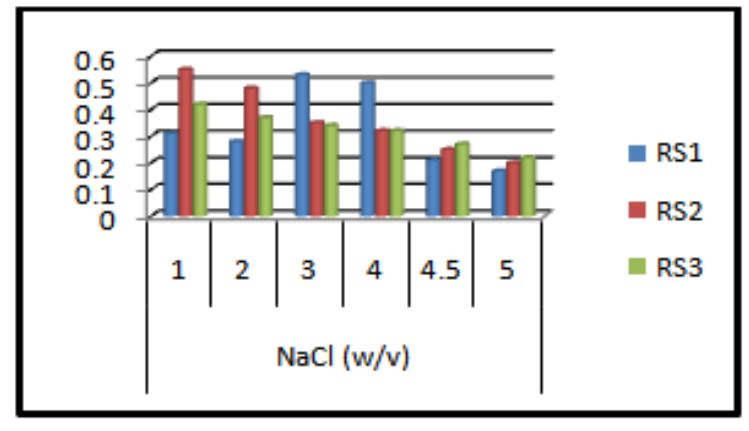

Figure 3: Tolerance of Rhizobium Strains to Nacl Concentrations 
Table 5: Identified of Rhizobium Species Isolated By 16S Rrna Amplification

\begin{tabular}{|l|l|l|l|l|l|}
\hline $\begin{array}{c}\text { Sr. } \\
\text { No. }\end{array}$ & Isolates & \multicolumn{1}{|c|}{ Type of Rhizobium } & \multicolumn{1}{|c|}{$\begin{array}{c}\text { Name of } \\
\text { Rhizobium }\end{array}$} & $\begin{array}{c}\text { Gene Bank } \\
\text { Accession No } \\
\text { Sequence ID }\end{array}$ & $\begin{array}{c}\text { Query } \\
\text { ID }\end{array}$ \\
\hline 1 & $\mathrm{RS}_{1}$ & Leguminosarum & ABDR1 & LC176423.1 & 151659 \\
\hline 2 & $\mathrm{RS}_{2}$ & $\begin{array}{l}\text { Sinorhizobium } \\
\text { meliloti }\end{array}$ & ABDR2 & LC176424.1 & 137359 \\
\hline 3 & $\mathrm{RS}_{3}$ & Rhizobium pusense & ABDR3 & LC176425.1 & 180517 \\
\hline
\end{tabular}

Table 5 shows results of PCR test of strains $\mathrm{RS}_{1}, \mathrm{RS}_{2}$ and $\mathrm{RS}_{3}$ and $16 \mathrm{~S}$ rRNA gene sequences by using NCBI BLAST for a known type of rhizobium that was isolated from a nodule of root Pea. One strain was leguminosarm, Sinorhizobium meliloti and Rhizobium pusense by user ID sequences as show in table i.e. the form of gene sequences in Gene bank

\section{ACKNOWLEDGEMENT}

I am highly indebted to my advisor for his guidance and constant supervision as well as for providing necessary information regarding the study. I express heartfelt thanks to the Hon'ble vice chancellor, HOD and advisor, department of soil science, (SHUATS) Allahabad, U. P., and Cytogene Research and Development Indira Nagar, Lucknow for providing all necessary facilities.

\section{REFERENCES}

1. Adewusi, H. G., Bada, S. O., Ladipo, D.O., and Husain, T. (2008) Nodulation in Militia Thonningii (Schum and Thonn) Baker Native Rhizobia and seed interaction from southwest Nigeria, Pakistan Journal of Botany, 40 (5): 2237-2242.

2. Afzal, A., \& Bano, A. (2008) Rhizobium and phosphate solubilizing bacteria improve the yield and phosphorus uptake in wheat (Triticum aestivum). International Journal Agriculture and Biology, 10(1): 85-88.

3. Arora, D. R. (2003) the text book of microbiology, New Delhi: CBS Publisher. P 41-48.

4. Ben-Gweirif, S. F., EI-Moshtty, F. I., and Agouri S. R. (2005) Effect of some Pesticides on different isolates of Rhizobium Leguminosarum in Libya, Proceeding Symposium, new trends in Science, 20-24.

5. Cappuccino and Sherman (2008) Microbiology a laboratory manual, eighth edition, Benjamin/ Cummings Publishing Company Inc, USA

6. Claus, G. W. (1989) Understanding microbes: a laboratory textbook for microbiology, Macmillan.

7. Collins CH, Patricia M, Lyne JM, Grange, Collins and Liyne's (1995) Edn, ButterworthHeinemann, UK. Page 117.

8. Deka, A. K and Azad, P. (2006) Isolation of Rhizobium strains cultural and Biochemical Characteristics, Journal Legume Reearch. 29 (3): 209-212.

9. Deshwal, V.K., Vig, K., Amisha, D. M., Yadav, P., Bhattacharya, D and Verma, M. (2011) Synergistic effects of the inoculation with plant growth-promoting Rhizobium and Pseudomonas on the performance of Mucuna, Annals of Forestry. 19(1): 13-20.

10. El-Mokadem, M.T., Helemish, F.A and Abdel-Wahab, S.M. (1991) Salt response of clover and alfalfa inoculated with salt tolerant strains of rhizobium, Ain Shams Science Bulletin, 28: 441-468.

11. Elsheikh, E. A and Wood, M. (1989) Response of chickpea and soybean rhizobia to salt: influence of carbon source, temperature and Ph, Soil Biology and Biochemistry 21: 883-887 
12. Elsoni, E.M and Osman, A.G. (2011) Effects of Bio-fertilization on Yield, Physical Characteristics and Chemical Composition of Pigeon Pea (Cajanus cajan L.), Pakistan Journal of Nutrition, 10(10): 978-981.

13. Embalomatis, A., Papaxosta, D. K., \& Katinakis, P. (1994) Evaluation of Rhizobium mdiloti Strains Isolated from Indigenous Populations in Northern Greece. Journal of Agronomy and Crop Science, 172(2): 73-80.

14. Facklam and Elliott, J. A. (1995) Identification, classification, and clinical relevance of catalase negative gram-positive cocciexcluding the streptococci and enterococci. Clinical Microbiology Reviews, 8 (4): 479. 21

15. Gao, J.L., Sun, J.G., Li, Y., Wang, E.T. and Chen, W.X. (1994) Numerical taxonomy and DNA relatedness of tropical rhizobia isolated from Hainan Province, International Journal of Systematic and Evolutionary, 44:151-158.

16. Hugh, R., \& Leifson, E. (1953) the taxonomic significance of fermentative versus oxidative metabolism of carbohydrates by various gram negative bacteria, Journal of bacteriology, 66(1): 24.

17. Hussain, M., M. Ashraf., M. Saleem and F. Y. Hafeez (2002) Isolation and Characterization of Rhizobium Strains From Alfalfa, Pakistan journal of agricultural sciences 39: 32-34.

18. Javed, K., Asghari, B. (2008) Potential allelopathic Effects of sunflowers on microorganisms, African Journal of Biotechnology, 7(22): 4208-4211.

19. MacFaddin, J. F. (2000) Biochemical tests for identification of medical bacteria, 3rd ed, Lippincott Williams \& Wilkins, Philadelphia, PA. 2000. p. 221-32.

20. Matiru, V. N., \& Dakora, F. D. (2004) Potential use of rhizobial bacteria as promoters of plant growth for increased yield in landraces of African cereal crops. African Journal of Biotechnology, 3(1): 1-7.

21. Mensah J.K., Esumeh, F., Iyam, M and Omoifo, C. (2006) Effect different salt concentration and pH on growth of rhizobium sp. and a cowpea - rhizobium ssocition. American-Eurasian journal of agricultural \& environmental sciences, 1 (3):198-202.

22. Oblisami, G. (1995) on in vitro growth of five species of ectomycorrhizal fungi, European Journal of Plant Pathology, 1(7): $204-210$.

23. Rafiq, S. (1997) Effects of different salt concentrations on the growth of Rhizobium (Osmoadaptation), Scientia journal, 1(2): $1-6$

24. Salisbury, W. A., \& Likos, J. J. (1972) Hydrolysis of casein: a differential aid for the indentification of Serratia marcescens. Journal of clinical pathology, 25(12): 1083-1085.

25. Singh, B., Kaur, $\boldsymbol{R}$ and Singh, $\boldsymbol{K}$. (2008) Characterization of Rhizobium strain isolated from the roots of Trigonella foenum graecum (fenugreek), African Journal of Biotechnology, 7(20): 3671-3676.

26. Singleton, P. W., El Swaify, S. A., \& Bohlool, B. B. (1982) Effect of salinity on Rhizobium growth and survival. Applied and Environmental Microbiology, 44(4), 884-890.

27. Vincent, J. M. (1970) A manual for the practical study of root nodule bacteria, IBP Hand book No. 15, Blackwell publication, oxford, U.K

28. Voges, O., \& Proskauer, B. (1898) Beitrag zur Ernährungsphysiologie und zur Differentialdiagnose der Bakterien der hämorrhagischen Septicämie. Zeitschrift für Hygiene und Infektionskrankheiten, 28(1): 20-32.

29. Willems, A. (2006) the taxonomy of rhizobia: an overview. Plant and soil, 287(1-2): 3-14. 

